\title{
P02.61. Does yogic breathing (pranayama) improve cardiovascular control?
}

\author{
S Bertisch ${ }^{1 *}, \mathrm{CTan}^{2}, \mathrm{~A} \mathrm{Ahn}{ }^{3}$, J Taylor $^{2}$ \\ From International Research Congress on Integrative Medicine and Health 2012 \\ Portland, Oregon, USA. 15-18 May 2012
}

\section{Purpose}

One proposed mechanism by which meditative practices improve cardiovascular health is via shifting sympathovagal balance. Yet few studies have examined the effects of these practices upon autonomic cardiovascular control. In this context, we hypothesized that yogic breathing differentially impacts heart period (RR-interval) and systolic blood pressure fluctuations compared with paced breathing at 15 breaths/minute.

\section{Methods}

We enrolled five healthy advanced yoga practitioners from diverse traditions. We continuously measured heart rate, beat-by-beat blood pressure, respiratory rate, inspiratory volume, and end-tidal $\mathrm{CO}_{2}$ during paced breathing (10 minutes) and yogic breathing (20 minutes). For yogic breathing, practitioners performed a deep breathing pranayama of their choice. We performed standard time and frequency domain analyses.

\section{Results}

In this group of practitioners, yogic breathing was characterized by a mean respiratory rate of $4.32 \pm 1.87$ breaths/ min, mean minute ventilation of $6.09 \pm 4.17 \mathrm{~L} / \mathrm{min}$, and mean end-tidal $\mathrm{CO}_{2}$ of $39.98 \pm 7.07 \mathrm{mmHg}$ compared with a mean respiratory rate of $15.0 \pm .60$ breaths $/ \mathrm{min}$, minute ventilation of $8.66 \pm 2.25 \mathrm{~L} / \mathrm{min}$, and mean endtidal $\mathrm{CO}_{2}$ of $32.68 \pm 5.22 \mathrm{mmHg}$ during paced breathing. The strength of the relationship (coherence) between respiration and heart period and respiration and systolic blood pressure did not differ between breathing patterns $(\mathrm{p}=0.74$ and $\mathrm{p}=0.14)$. However, we found increased gain between respiration and heart period fluctuations $(400.00 \pm 154.19 \mathrm{msec} / \mathrm{L}$ vs $36.65 \pm 10.32 \mathrm{mmHg} / \mathrm{L}$, $\mathrm{p}=0.02$ ) and between respiration and systolic blood

${ }^{1}$ Beth Israel Deaconess Medical Center, Boston, USA

Full list of author information is available at the end of the article pressure fluctuations $(15.97 \pm 9.32 \mathrm{msec} / \mathrm{L}$ vs $1.68 \pm 0.68$ $\mathrm{mmHg} / \mathrm{L}, \mathrm{p}=0.02$ ) during yogic breathing compared with paced breathing.

\section{Conclusion}

Yogic breathing was associated with increased gain compared with paced breathing. Whether the larger gain relation between respiration and cardiovascular fluctuations during yogic breathing represents baroreflex modulation or is due to enhanced entrainment through repetitive practice remains to be established. However, these preliminary findings may explain some of yoga's reported cardiovascular benefits.

\section{Author details}

${ }^{1}$ Beth Israel Deaconess Medical Center, Boston, USA. ${ }^{2}$ Spaulding Rehabilitation Hospital, Harvard Medical School, Boston, USA. ${ }^{3}$ Massachusetts General Hospital, Harvard Medical School, Boston, USA.

Published: 12 June 2012

doi:10.1186/1472-6882-12-S1-P117

Cite this article as: Bertisch et al:: P02.61. Does yogic breathing

(pranayama) improve cardiovascular control? BMC Complementary and Alternative Medicine 2012 12(Suppl 1):P117.

Submit your next manuscript to BioMed Central and take full advantage of:

- Convenient online submission

- Thorough peer review

- No space constraints or color figure charges

- Immediate publication on acceptance

- Inclusion in PubMed, CAS, Scopus and Google Scholar

- Research which is freely available for redistribution
C Biomed Central

ㄷ 2012 Bertisch et al; licensee BioMed Central Ltd. This is an Open Access article distributed under the terms of the Creative Commons Attribution License (http://creativecommons.org/licenses/by/2.0), which permits unrestricted use, distribution, and reproduction in any medium, provided the original work is properly cited. 